\title{
Does intensive feeding frequency affect growth performance of common snook Centropomus undecimalis (Bloch, 1792)?
}

\author{
L. A. Herrera ${ }^{a}$, V. V. Kuhnen ${ }^{a}$ and E. G. Sanches ${ }^{a} *$ \\ anstituto de Pesca, Agência Paulista de Tecnologia do Agronegócio, Secretaria da Agricultura e Abastecimento, \\ Av. Cais do Porto, 2275, CEP 11680-000, Ubatuba, SP, Brasil \\ *e-mail: esanches@pesca.sp.gov.br
}

Received: October 10, 2017 - Accepted: December 8, 2017 - Distributed: August 31, 2019

(With 2 figures)

\begin{abstract}
Salt water recirculation systems using automatic feeders are a new frontier for marine aquaculture. It is possible to decrease the vulnerability of the traditional fish farming in open systems and reduce wasteful feeding and discharge of effluents, as well as increase the economic returns. An experiment with common snook fingerings $(4.31 \pm 1.42 \mathrm{~g}$ and $8.4 \pm 1.0 \mathrm{~cm}$ ) was performed. Three feeding treatments were evaluated: six, twelve and eighteen feeding times per day. Each treatment had three replications. Among the three tested frequencies (fed 6,12 and 18 times a day), the feeding frequency of 12 times per day (every two hours) showed the best values of the parameters evaluated for production performance. The final weight values, condition factor, specific growth rate and daily weight gain of the treatment 12 feeding times per day were all significantly higher than the lower and higher frequencies. Our results demonstrate that high feeding frequency is not synonymous of higher performance, but is extremely necessary to find out the best range for the target species. Besides, this relationship between feeding frequency and growth performance might change over weight range. Therefore, future studies should address higher weight ranges for comparison to our results.
\end{abstract}

Keywords: recirculation aquatic system, authomatic feeders, mariculture.

\section{A utilização de frequência alimentar elevada pode afetar o desempenho produtivo do robalo flecha Centropomus undecimalis (Bloch, 1792)?}

\section{Resumo}

Sistemas de recirculação de água salgada utilizando alimentadores automáticos são uma nova fronteira para a aquicultura marinha. Possibilitam diminuir a vulnerabilidade dos cultivos em sistemas abertos e conferir redução de desperdício de ração e lançamento de efluentes, assim como elevar o retorno econômico. Foi realizado um experimento com juvenis de Robalo-flecha $(4,31 \pm 1,42 \mathrm{~g}$ e 8,4 $\pm 1,0 \mathrm{~cm})$. Três frequências alimentares foram avaliadas: alimentação seis vezes ao dia; doze vezes ao dia, e; dezoito vezes ao dia. Cada tratamento teve três repetições. Dentre as três frequências avaliadas a frequência alimentar de 12 vezes ao dia foi a que apresentou os melhores valores para os parâmetros zootécnicos avaliados. Os valores obtidos de peso final, fator de condição, taxa de crescimento específico e ganho de peso diário foram todos maiores para a frequência de 12 vezes ao dia do que os obtidos para as frequências maior e menor. Nossos resultados demonstram que elevadas frequências alimentares não são sinônimo de melhor desempenho produtivo, mas é extremamente importante conhecer a frequência ideal para a espécie a ser cultivada. Além disto, a relação entre frequência alimentar e crescimento pode mudar de acordo com a faixa de peso dos indivíduos. Desta forma, é extremamente importante que trabalhos futuros avaliem as frequências aqui estudadas para comparar os resultados em indivíduos maiores.

Palavras-chave: sistema de recirculação, alimentadores automáticos, maricultura.

\section{Introduction}

The common snook Centropomus undecimalis (Bloch, 1792) is a marine finfish, that occurs from the United States to Southern of Brazil. The species has resilience to traditional management systems used in aquaculture enterprises (Nunes, 2013). The economic viability of the species has been proven (Sanches et al., 2014a) and several scientific advances have been made to optimize the supply of young forms to producers (Ibarra-Castro et al., 2011; Sanches et al., 2013). However, there is still a lack of knowledge about optimal management practices that can lead to the expression of all their full potential as an aquaculture candidate. Among the different management 
practices required for the fish culture, the choice of adequate food often has proved to be an important tool to improve performance of cultured species (Lawrence et al., 2012).

Feeding frequency is a measure that defines how many times the food will be offered throughout the twenty-four hours per day. The use of a high feeding frequency promotes better growth, more homogeneous lots (lower coefficient of variation), a high survival rate, and lower feed conversion ratio, while minimizing the release of waste and contribute to reducing environmental impacts of fish farms (Cunha et al., 2013). Moreover, inadequate feeding frequencies can slow fish growth rates, increase intra-specific aggression and cannibalism rates, decrease intestinal enzyme activity, and reduce the hepatic expression (IGF-I); consequently, causing significant economic losses and reduce profitability of fish farms (Booth et al., 2008; Tian et al., 2015). The appropriate feeding frequency to be offered for one species will depend on intake capacity of its stomach, structure of its digestive system, and digestion and disposal rates (Kucska et al., 2007).

Carnivorous species like common snook, have large stomachs and a short intestine when compared to omnivorous and herbivorous fishes. Consequently, carnivorous fish would be capable of ingesting large amounts of food and have a slow digestion (Kubitza and Lovshin, 1998). It would be expected therefore that these species reach satiation quickly and would not benefit from the increase in feeding rate. This premise is supported by the fact that most studies of carnivorous marine fish use low feeding frequencies instead of multiple meals throughout a day (Garcia-Galano et al., 2003; Souza-Filho and Cerqueira, 2003; Tsuzuki and Berestinas, 2008; Corrêa et al., 2010; Sanches et al., 2014b).

The supply of food a few times per day is a widespread practice among fish farmers mainly due to the difficulties associated with food handling (Sanches and Kuhnen, 2016). However, this difficulty can be achieved by employing automatic feeders. The use of automatic feeders allows to divide the total daily amount of food at regular intervals; also enables the feeding during the night and reduces the interference of the handler (Zhou et al., 2003; Sousa et al., 2008). Most marine fish farming ventures in Brazil still hold the feeding manually twice a day (Sanches and Kuhnen, 2016).

Our hypothesis is that the practice of feeding management, which has been adopted ( 2 to 4 times a day, Corrêa et al., 2010) may be inadequate to achieve the better growth performance of the species. Thus, this study aimed to evaluate the performance of juvenile common snook under high feeding frequencies.

\section{Material and Methods}

At the beginning of the experiment, 135 juveniles of common snook, were obtained by breeding in captivity. These fingerings were weighing $4.34 \pm 1.42 \mathrm{~g}$ and measuring $8.4 \pm 1.0 \mathrm{~cm}$ total length. They were collected 90 days after hatching and evaluated in three feeding frequencies: six (every 4 hours), twelve (every 2 hours) and eighteen times per day (every 1.3 hours). Each treatment had three replicates, totaling nine tanks, each tank received fifteen fishes. The circular tanks had the capacity of 150 liters.

All tanks were maintained in salt water recirculation system with mechanical filtration (100 microns), skimmer filter and ultraviolet lamps. Before entering the system all the fish were weighed, measured and underwent a freshwater bath for 5 minutes aiming to eliminate any ectoparasites (Kerber et al., 2011). Each tank received an automatic feeder unit (SOMA Fish WT180) with a storage capacity of $50 \mathrm{~g}$ of food. Feed used was from a commercial marine finfish with particle sizes between 1 and $2 \mathrm{~mm}$ diameter. Feed chemical composition indicated by the manufacturer was: crude protein $41.8 \%$, lipid $8.75 \%$, ash $6.77 \%$, brute fiber $1,96 \%$.

The experiment lasted 60 days. Every week, fishes weight was measured to calculate the feed amount to be offered based on the feed rate of $2.5 \%$ live weight. As a daily operation practice, the occurrence of mortalities was recorded. To clean the bottom of the tanks, every day about $5 \%$ of the tank volume was removed by siphon. This water volume, plus the amount of water loosed by evaporation, were replaced with deionized water. The water quality parameters were measured in the discharge channel were water from all tanks converging for recirculating system. The temperature and dissolved oxygen content of the water system were monitored with an oximeter YSI model 51 (Yellow Springs Instrument Company, Yellow Springs, Ohio, USA). Total ammonia was monitored by colorimetric method with a Tetratest ${ }^{\circledR}$ Kit (Tetra Werke, Melle, Germany) and salinity with an optical refractometer F3000 (Bernauer Aquaculture, Blumenau, Brazil). The $\mathrm{pH}$ and ORP were measured using pH-ORP controller (PH-303) (Omega Engineering Inc., Taiwan).

Sampling was carried out in all animals before the start and end of the experiment, using ruler and digital electronic scale (precision $0.01 \mathrm{~g}$ ). To perform the biometric, individuals were anaesthetized with benzocaine $\left(0.05 \mathrm{~g} \mathrm{~L}^{-1}\right.$ water $)$ and then, measured and weighed individually. After each biometry, the increase of biomass was considered to define the new quantity of food to be supplied.

The following performance parameters were calculated (Equations 1-5):

$$
\begin{aligned}
& \text { Survival rate }=\frac{\text { live fish }}{\text { initial number of fishes }} \times 100 \\
& \text { Condition factor }=\frac{\text { final weight }}{(\text { final lenght })^{3}} \times 100
\end{aligned}
$$

Specific growth rate $=\frac{\ln \text { final weight }-\ln \text { initial weight }}{\text { number of days of the trial period }} \times 100$

Daily weight gain $=\frac{\text { final weight }- \text { initial weight }}{\text { number of days of the trial period }}$

Feed convertion ratio $=\frac{\text { Total amount of feed consumed in the period }}{\text { total } \text { weight } \text { gain in the trial }}$ 


\subsection{Data analysis}

The experiment was conducted in a completely randomized design. To compare the treatments the mean parameters were subjected to analysis of variance (ANOVA). The values expressed in percentage (survival) were arcsine transformed before analysis. In case of significant differences, a Tukey's test was applied $(\mathrm{P}<0.05)$.

\section{Results}

Water quality parameters showed that the system used for recirculation was effective in maintaining the quality of water suitable for the maintenance of the common snook. Temperature: $28.2 \pm 1.5^{\circ} \mathrm{C}$; Salinity: $32.3 \pm 21$; Dissolved oxygen: $6.2 \pm 0.6 \mathrm{mg} \mathrm{L}-1$; Saturation: $96.7 \pm 1.6 \%$; Total ammonia: $0.1 \pm 0.1 \mathrm{mg} \mathrm{L}^{-1}$; $\mathrm{pH}: 8.0 \pm 0.4$; Oxide-reduction potential: $\left.261.2 \pm 9.3 \mu \mathrm{Scm}^{-1}\right)$.

Among the three tested frequencies (fed 6, 12 and 18 times a day), the feeding frequency of 12 times per day showed the best values of the parameters evaluated for production performance (Table 1).

The final weight values, condition factor, specific growth rate and daily weight gain were all significantly higher in individuals fed 12 times per day. Moreover, feed conversion ratio of this treatment was also significantly lower than the others. Only the length and survival rates showed no significant differences among treatments. Despite being evident that high feeding frequency is able to reflect positively on the performance of common snook, this relationship is not linear. The lower and higher frequencies had undesired results, and the intermediate frequency of 12 times per day showed the best results (Figures 1 and 2).

\section{Discussion}

Our results demonstrate that the interspaced feeding every two hours is the optimum feeding frequency for juveniles of the species, but the increase in this frequency was no better performance monitoring. Similar results have shown that high feeding frequency is also advantageous for other fish species (Zhou et al., 2003; Sousa et al., 2008; Bascinar et al., 2007; Canton et al., 2007; Kasiri et al., 2011).
Several studies have shown that excessive rise in food often results in reduced feed conversion (Cunha et al., 2013). García-Galano et al. (2003) observed that the gastric evacuation time to common snook decreases as it expands its feeding frequency. In their study, the time in which it reached $100 \%$ of gastric emptying was 16 hours for fish fed one time per day, 10 hours for those fed 2 times per day and 5 hours for which they were hand fed 3 times per day. These results demonstrated that the common snook has ability to adjust their gastric emptying time regarding the amount of time the food is offered. In our

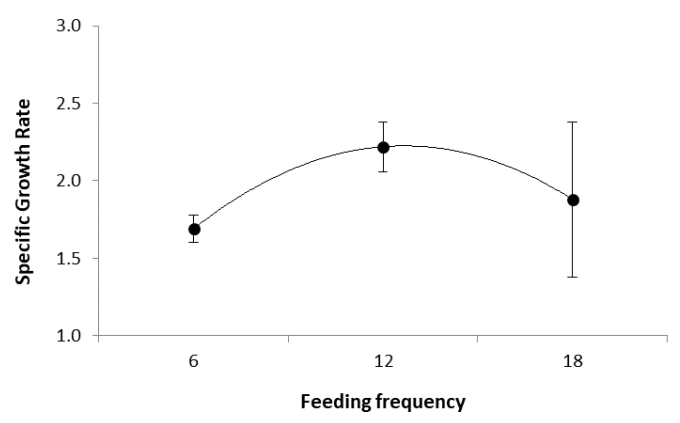

Figure 1. Relationship between feeding frequency and specific growth rate for common snook juvenile Centropomus undecimalis.

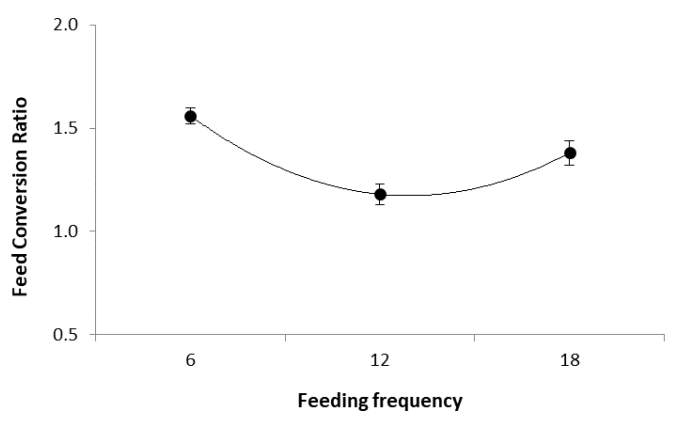

Figure 2. Relationship between feeding frequency and feed conversion ratio for juvenile common snook Centropomus undecimalis.

Table 1. Productive performance parameters commom snook Centropomus undecimalis submitted to different feeding frequencies for 60 days $(n=3)^{1}$.

\begin{tabular}{|c|c|c|c|c|c|}
\hline \multirow{2}{*}{ Parameter } & \multicolumn{2}{|c|}{ ANOVA model results } & \multicolumn{3}{|c|}{ Times of feeding per day } \\
\hline & $\mathbf{F}$ & $\mathbf{p}$ & 6 & 12 & 18 \\
\hline Length $(\mathrm{cm})$ & 5.05 & $<0.01$ & $11.1 \pm 1.0^{\mathrm{b}}$ & $11.9 \pm 1.4^{\mathrm{a}}$ & $11.8 \pm 1.4^{\mathrm{a}}$ \\
\hline Weight (g) & 8.08 & $<0.01$ & $11.97 \pm 3.16^{b}$ & $16.07 \pm 5.70^{\mathrm{a}}$ & $13.54 \pm 4.76^{b}$ \\
\hline Factor condition $(\mathrm{K})$ & 13.74 & $<0.01$ & $0.86 \pm 0.03^{b}$ & $0.95 \pm 0.04^{\mathrm{a}}$ & $0.81 \pm 0.04^{b}$ \\
\hline Survival rate $(\%)$ & 0.00 & 0.99 & $97.6 \pm 4.2$ & $97.6 \pm 4.2$ & $97.6 \pm 4.2$ \\
\hline Specific Growth Rate $\left(\% \mathrm{BW} \mathrm{dia}^{-1}\right)$ & 6.20 & 0.03 & $1.69 \pm 0.09^{b}$ & $2.22 \pm 0.16^{\mathrm{a}}$ & $1.88 \pm 0.50^{b}$ \\
\hline Daily Weight Gain (g dia $\left.{ }^{-1}\right)$ & 11.03 & 0.01 & $0.13 \pm 0.02^{b}$ & $0.20 \pm 0.04^{\mathrm{a}}$ & $0.15 \pm 0.05^{b}$ \\
\hline Feed Convertion Ratio & 41.72 & $<0.01$ & $1.56 \pm 0.04^{\mathrm{c}}$ & $1.18 \pm 0.05^{\mathrm{a}}$ & $1.38 \pm 0.06^{\mathrm{b}}$ \\
\hline
\end{tabular}

${ }^{1}$ Lines with different letters indicate significant differences between treatments $(\mathrm{P}<0.05)$. 
experiments the best feed conversion ratio was obtained with feeding frequency of 12 times per day. Therefore, it is possible to suppose that feeding the common snook at 12 times per day allowed a time interval between meal most appropriate to its digestive physiology than lower or higher feed frequencies. Consequently, its intestinal peristalsis and the rate of food passage through the tract was properly stimulated, thereby increasing weight gain associated to a low food conversion rate.

Feed conversion rate may vary among marine finfishes, but also depends of age and weight of individuals. For fishes within the weight range used in this study, feed conversion ratio slower than 1.5 may be considered very significant optimized performance (Sun et al., 2014). Therefore, our feed conversion rate obtained in the treatment of timer per day feed frequency $(1.18 \pm 0.05)$ can be considered extremely satisfactory and results in lower cost of production associated to lower environmental impacts (Norði et al., 2011).

The use of automatic feeders is an excellent tool to offer with ease and precision high feeding frequency. In our experiment, realized with automatic feeders, we obtained lower feed conversion rate compared to other studies also performed with fat snook but that had used manual feeding and low feed frequencies. For example, Ostini et al. (2007) report FCR between6.7 and 7.1 while Sanches et al. (2011) found FCR ranging from 1.5 to 2.2. The practice of manually feeding the fish to satiation is a methodology that inserts a significant amount of variability and may mask the results between treatments. In addition, the manual supply is directly related to attendant subjectivity which can cause losses in feed conversion.

Better feed conversion ratio is directly reflected in production costs. It is possible to decrease the feed conversion ratio through an increase in feed frequency, and consequently, save an equivalent of $360 \mathrm{~kg}$ of feed for each ton of fish produced (Sousa et al., 2008). Our results demonstrate that there is an average increase of biomass by $25 \%$ from best to worst outcome. Although there are no studies that evaluate the economic feasibility of using automatic feeders in Brazil, this productivity gain indicate advantages in adopting this technology. Water quality parameters showed that the system used for recirculation was effective in maintaining the quality of water suitable for the maintenance of the species. The values were all within the variation range considered suitable for snook culture (Ferraz and Cerqueira, 2010; Oliveira et al., 2013). Thus, our results demonstrate the feasibility of common snook juveniles growing in salt water recirculation systems.

Only by incorporating technologies in fish farm will be possible to meet peculiar demands of each species. For juvenile common snook, the ideal feeding frequency is regular feedings every two hours, which is not feasible to run without the use of automatic feeders. From the knowledge of the intrinsic needs of the species, and the adoption of an aquaculture precision to management practices adjusted to these needs, the desired improvement in commom snook cultivation can be achieve.

\section{Conclusions}

For juveniles of common snook, the optimum feeding frequency is at regular intervals of two hours.

For juvenile common snook, feed frequencies higher or lower than the optimum results in lower weight gain.

The results presented in this study are specific for the studied weight range of common snook. Future studies should overcome this limitation and address higher weight ranges for comparison of results.

\section{Acknowledgements}

The authors treat their acknowledgment to FAPESP (Foundation of São Paulo Research) for financing this project (process 2014/07886-7).

\section{References}

BAŞÇINAR, N., ÇAKMAK, E., ÇAVDAR, Y. and AKSUNGUR, N., 2007. The effect of feeding frequency on growth performance and feed conversion rate of black sea trout (Salmo trutta labrax Pallas, 1811). Turkish Journal of Fisheries and Aquatic Sciences, vol. 7, pp. 13-17.

BOOTH, M.A., TUCKER, B.J., ALLAN, G.L. and FIELDER, D.S., 2008. Effect of feeding regime and fish size on weight gain, feed intake and gastric evacuation in juvenile Australia snapper Pagrus auratus. Aquaculture, vol. 282, no. 1-4, pp. 104-110. http://dx.doi.org/10.1016/j.aquaculture.2008.06.027.

CANTON, R., WEINGARTNER, M., FRACALOSSI, D.M. and ZANIBONI FILHO, E., 2007. Influência da freqüência alimentar no desempenho de juvenis de jundiá. Revista Brasileira de Zootecnia, vol. 36, no. 4, pp. 749-753. http://dx.doi.org/10.1590/ S1516-35982007000400001.

CORREAA, C.F., LEONARDO, A.F.G., TACHIBANA, L. and CORRÊA-JUNIOR, L., 2010. Frequência alimentar para juvenis de robalo-peva criados em água doce. Revista Academica Ciências Agrárias Ambientais, vol. 8, pp. 429-436.

CUNHA, V.L., SHEI, M.R.P., OKAMOTO, M.H., RODRIGUES, R.V. and SAMPAIO, L.A., 2013. Feeding rate and frequency on juvenile pompano growth. Pesquisa Agropecuária Brasileira, vol. 48, no. 8, pp. 950-954. http://dx.doi.org/10.1590/S0100$204 X 2013000800020$.

FERRAZ, E.M. and CERQUEIRA, V.R., 2010. Influência da temperatura na maturação gonadal de machos de robalo-flecha, Centropomus undecimalis. Boletim do Instituto de Pesca, vol. 36, no. 2, pp. 73-83.

GARCÍA-GALANO, T., PÉREZ, J.C., GAXIOLA, G. and SÁNCHEZ, A., 2003. Effect of feeding frequency on food intake, gastric evacuation and growth in juvenile snook, Centropomus undecimalis (Bloch). Revista de Investigaciones Marinas, vol. 24, no. 2, pp. 145-154.

IBARRA-CASTRO, L., ALVAREZ-LAJONCHÈRE, L., ROSAS, C., PALOMINO-ALBARRAN, I.G., HOLT, J.G. and SANCHEZ-ZAMORA, A., 2011. GnRHa-induced spawning with natural fertilization and a pilot-scale juvenile mass production of common snook, Centropomus undecimalis (BLOCH,1792). Aquaculture, vol. 319, no. 3-4, pp. 479-483. http://dx.doi. org/10.1016/j.aquaculture.2011.07.014. 
KASIRI, M., FARAHI, A. and SUDAGAR, M., 2011. Effects of feeding frequency on growth performance and survival rate of angel fish, Pterophyllum scalare (Perciformes: Cichlidae). Veterinary Research Forum: An International Quarterly Journal, vol. 2, pp. 97-102.

KERBER, C.E., SANCHES, E.G., SANTIAGO, M. and LUQUE, J.L., 2011. First record of Neobenedenia melleni (Monogenea: Capsalidae) in sea-farmed cobia (Rachycentron canadum) in Brazil. Revista Brasileira de Parasitologia Veterinária, vol. 20, no. 4, pp. 331-333. http://dx.doi.org/10.1590/S1984-29612011000400013. PMid:22166389.

KUBITZA, F. and LOVSHIN, L.L., 1998. Formulated diets, feeding strategies, and cannibalism control during intensive culture of juvenile carnivorous fishes. Reviews in Fisheries Science, vol. 7, no. 1, pp. 1-22. http://dx.doi.org/10.1080/10641269991319171.

KUCSKA, B., MÜLLER, T. and BERCSÉNYI, M., 2007. The effect of feeding frequency on the growth and survival of pike (Esox lucius L.) using floating pellets. Journal of Applied Ichthyology, vol. 23, no. 2, pp. 193-194. http://dx.doi.org/10.1111/j.14390426.2006.00809.x.

LAWRENCE, C., BEST, J., JAMES, A. and MALONEY, K., 2012. The effects of feeding frequency on growth and reproduction in zebrafish (Danio rerio). Aquaculture, vol. 368, pp. 103-108. http://dx.doi.org/10.1016/j.aquaculture.2012.09.022.

NORĐI, G., GLUD, R.N., GAARD, E. and SIMONSEN, K., 2011. Environmental impacts of coastal fish farming: carbon and nitrogen budgets for trout farming in Kaldbaksfjørður (Faroe Islands). Marine Ecology Progress Series, vol. 431, pp. 223-241. http://dx.doi.org/10.3354/meps09113.

NUNES, AJP., 2013. Perspectivas da piscicultura marinha no Nordeste do Brasil. Revista da Associação Brasileira dos Criadores de Camarão, vol. 151, no. 1, pp. 50-55.

OLIVEIRA, L.A.A.G., ALMEIDA, A.M., PANDOLFO, P.S.V., SOUZA, R.M., FERNANDES, L.F.L. and GOMES, L.C., 2013. Crescimento e produtividade de juvenis de robalo-peva a diferentes temperaturas e taxas de alimentação. Pesquisa Agropecuária Brasileira, vol. 48, no. 8, pp. 857-862. http://dx.doi.org/10.1590/ S0100-204X2013000800007.

OSTINI, S., OLIVEIRA, I.R., SERRALHEIRO, P.C.S. and SANCHES, E.G., 2007. Criação do robalo-peva (Centropomus parallelus) submetido a diferentes densidades de estocagem. Revista Brasileira de Saúde e Produção Animal, vol. 8, no. 3, pp. 250-257.

SANCHES, E.G. and KUHNEN, V.K., 2016. Quantos peixes tem no mar? Aquaculture Brasil, vol. 2, pp. 20-25.
SANCHES, E.G., MELLO, G.L. and AMARAL-JUNIOR, H., 2013. Primeira ocorrência de malformação na coluna vertebral em juvenis de robalo-flecha. Boletim do Instituto de Pesca, vol. 39 , no. 1 , pp. $77-83$.

SANCHES, E.G., OLIVEIRA, I.R., SERRALHEIRO, P.C.S. and OSTINI, S., 2011. Cultivo do robalo peva Centropomus parallelus em sistema de recirculação. Arquivos de Ciências do Mar, vol. 44, no. 1, pp. 40-46.

SANCHES, E.G., SILVA, F.C. and RAMOS, A.P.F.A., 2014a. Viabilidade econômica do cultivo do robalo-flecha em empreendimentos de carcinicultura no Nordeste do Brasil. Boletim do Instituto de Pesca, vol. 40, no. 4, pp. 577-588.

SANCHES, E.G., SILVA, F.C., LEITE, J.R., SILVA, P.K.A., KERBER, C.E. and SANTOS, P.A., 2014b. A incorporação de óleo de peixe na dieta pode melhorar o desempenho da garoupaverdadeira Epinephelus marginatus? Boletim do Instituto de Pesca, vol. 40, no. 2, pp. 147-155.

SOUSA, R.M.R., AGOSTINHO, C.A., OLIVEIRA, F.A., ARGENTIM, D., NOVELLI, P.K. and AGOSTINHO, S.M.M., 2008. Productive performance of Nile tilapia (Oreochromis niloticus) fed at different frequencies and periods with automatic dispenser. Arquivo Brasileiro de Medicina Veterinária e Zootecnia, vol. 64 , no. 1, pp. 192-197. http://dx.doi.org/10.1590/S010209352012000100027.

SOUZA-FILHO, J.J. and CERQUEIRA, V.R., 2003. Influência da densidade de estocagem no cultivo de juvenis de robalo flecha mantidos em laboratório. Pesquisa Agropecuária Brasileira, vol. 38, no. 11, pp. 1317-1322. http://dx.doi.org/10.1590/S0100204X2003001100010.

SUN, G., ZHENG, J., LIU, B. and LIU, Y., 2014. Effects of feeding rate and frequency on growth performance, digestion and nutrients balances of Atlantic salmon (Salmo salar) in recirculating aquaculture systems (RAS). Aquaculture Research, vol. 2, pp. 1-13. http://dx.doi.org/10.1111/are.12480.

TIAN, H.Y., ZHANG, D.D., LI, X.F., ZHANG, C.N., QIAN, Y. and LIU, W.B., 2015. Optimum feeding frequency of juvenile blunt snout bream Megalobrama amblycephala. Aquaculture, vol. 437, pp. 60-66. http://dx.doi.org/10.1016/j.aquaculture.2014.11.032.

TSUZUKI, M.Y. and BERESTINAS, A.C., 2008. Desempenho de juvenis de robalo-peva Centropomus parallelus com diferentes dietas comerciais e freqüências alimentares. Boletim do Instituto de Pesca, vol. 34, no. 4, pp. 535-541.

ZHOU, Z., CUI, Y., XIE, S., ZHU, X., LEI, W., XUE, M. and YANG, Y., 2003. Effect of feeding frequency on growth, feed utilization, and size variation of juvenile gibel carp (Carassius auratus gibelio). Journal of Applied Ichthyology, vol. 19, no. 4, pp. 244-249. http://dx.doi.org/10.1046/j.1439-0426.2003.00453.x. 